\title{
PENGARUH KEPATUHAN DAN PENGAWASAN TERHADAP KUALITAS LAPORAN KEUANGAN PEMERINTAH DAERAH (STUDI EMPIRIS PADA PEMERINTAH KABUPATEN MINAHASA UTARA)
}

\author{
Nikita Srisilia Mawuntu ${ }^{1}$, Hendrik Manossoh ${ }^{2}$, Dhullo Afandi ${ }^{3}$ \\ ${ }^{1,2,3}$ Jurusan Akuntansi, Fakultas Ekonomi dan Bisnis, Universitas Sam Ratulangi, Jl. Kampus Bahu, Manado, \\ 95115, Indonesia \\ E-mail: nikimawuntu@gmail.com
}

\begin{abstract}
Local Government Financial Statement is an information media for the society that gives information about the financial position and the performance of local government. Therefore, a financial statement should be qualified, reliable, accountable and transparent to meet the public requirement. Some factors are considered capable to improve the quality of Local Government Financial Statement. They are compliance with the rule of law and internal control. This study aims to obtain empirical evidence of the influence of compliance to the rule of law and internal control toward the quality of Minahasa Utara Regency Government Financial Statement. There are 60 respondents as the samples have been taken from 24 Local Government Organization used in this research. It uses quantitative analysis method and questionnaire instrument as primary data collection and process the data by SPSS version 23. The statistic method that used to verify the hypothesis is by multiple linear regression analysis. The hypothesis test results show that compliance to the rule of law has a positive and significant effect to the quality of Local Government Financial Statement while internal control has no significant and positive influence to the Financial Statement of Minahasa Utara Regency Government.
\end{abstract}

Keywords: compliance; internal control; financial statement

\section{PENDAHULUAN}

Laporan keuangan merupakan alat komunikasi bagi pemerintah untuk memberikan informasi kinerja keuangan bagi pihak internal maupun eksternal (Sholohah et al., 2019). Laporan keuangan pemerintah yang berkualitas menjamin para pengguna laporan keuangan dalam mengambil dan menentukan keputusan yang tepat serta meningkatkan kepercayaan masyarakat akan aktivitas dan pengelolaan dana juga kinerja dari pemerintah, sehingga pemerintah harus memastikan bahwa laporan keuangan pemerintah daerah tersusun dan tersaji sesuai yang diatur dalam peraturan pemerintah. Selain itu laporan keuangan yang berkualitas bukan saja hanya berorientasi pada luaran melainkan juga pada pelaksanaan kegiatan pemerintahan sehingga dari kegiatan yang terlaksana dengan baik, efektif, efisien dan bebas dari penyelewengan pun menghasilkan laporan keuangan yang andal. Pada kenyataannya, temuan di lapangan oleh Badan Pemeriksa Keuangan (BPK) terkait masalah kelemahan Sistem Pengendalian Internal dan Ketidakpatuhan akan Peraturan UndangUndang masih banyak jumlahnya bahkan meningkat pada beberapa tahun terakhir.

Gambar 1 menunjukkan bahwa jumlah permasalahan yang ditemukan BPK dalam Laporan Keuangan Pemerintah Daerah (LKPD) dari semester satu ke semester satu tahun berikutnya terjadi peningkatan. Hal ini mengidentifikasikan bahwa belum terjadi perbaikan yang signifikan dari pemerintah daerah terkait permasalahan tersebut. Jika hal ini terus berlangsung, dalam arti pemerintah belum mengikuti sepenuhnya pada peraturan UndangUndang serta Sistem Pengendalian Internal masih belum bisa dikontrol dengan baik, maka kualitas laporan keuangan pemerintah daerah tidak akan optimal. 


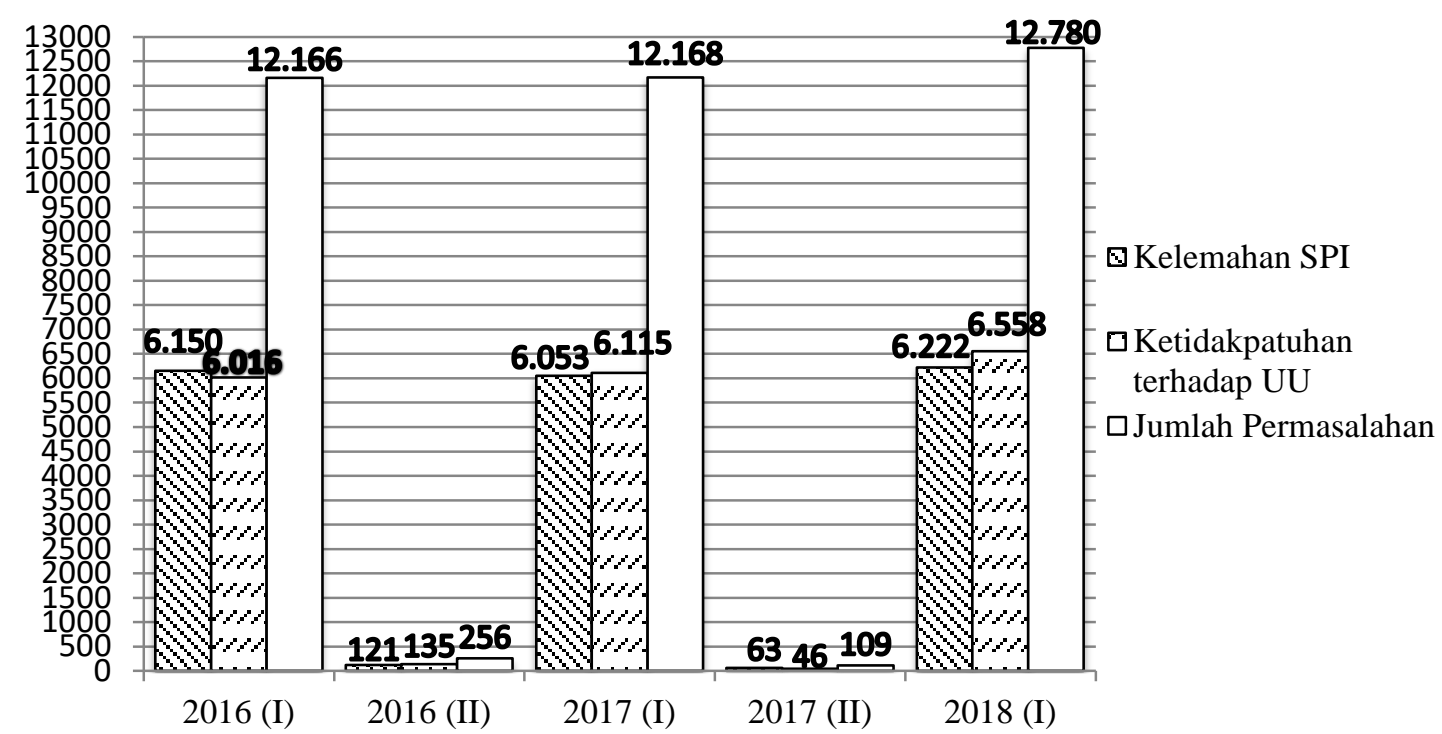

Gambar 1. Grafik perkembangan temuan BPK terkait permasalahan LKPD dalam IHPS tahun 2016 s.d 2018

Peraturan Pemerintah yang mengatur mengenai penyusunan dan penyajian laporan keuangan pemerintah agar menjadi berkualitas adalah PP Nomor 71 Tahun 2010 tentang Standar Akuntansi Pemerintahan dan mengenai kontrol aktivitas pemerintah diatur dalam PP Nomor 60 Tahun 2008 tentang Sistem Pengendalian Internal Pemerintah. Kedua hal ini merupakan penunjang dan faktor dalam mewujudkan laporan keuangan pemerintah yang berkualitas sehingga penelitian ini bertujuan untuk memberikan bukti empiris atas laporan keuangan di Kabupaten Minahasa Utara.

Motivasi penelitian ini juga adalah karena terdapat inkonsistensi pada hasil penelitian sebelumya yang mana ada yang menyatakan kepatuhan akan perundang-undangan dan pengawasan internal berpengaruh atas peningkatan kualitas laporan keuangan dan ada pula yang menyatakan tidak berpengaruh di masing-masing daerah sehingga diharapkan hasil dari penelitian ini dapat menginformasikan pada pemerintah khususnya pemerintah Kabupaten Minahasa Utara akan faktor-faktor apa saja yang dapat mempengaruhi kualitas laporan keuangan pemerintah dan yang perlu dipertahankan serta diperbaiki.

\section{TINJAUAN PUSTAKA}

Akuntansi sebagai bahasa bisnis merupakan sebuah sistem informasi yang mengukur aktivitas bisnis, pemrosesan data menjadi laporan dan mengkomunikasikan hasilnya kepada para pengambil keputusan (Pontoh, 2013). Laporan keuangan merupakan media informasi yang relevan mengenai posisi keuangan dan seluruh transaksi yang dilakukan oleh entitas pelaporan selama satu periode pelaporan. Laporan keuangan digunakan untuk mengetahui nilai sumber daya ekonomi yang dipakai untuk menjalankan kegiatan operasional pemerintahan, menilai kondisi keuangan, mengevaluasi efektivitas dan efisiensi suatu entitas pelaporan dan membantu menentukan ketaatan terhadap peraturan perundang-undangan. Komponen Laporan Keuangan Pemerintah yaitu terdiri dari: Laporan Realisasi Anggaran, Laporan Perubahan Saldo Anggaran Lebih, Neraca, Laporan Operasional, Laporan Arus Kas, Laporan Perubahan Ekuitas, dan Catatan atas Laporan Keuangan (Peraturan Pemerintah Republik Indonesia tentang SAP, 2010). Laporan keuangan yang berkualitas yaitu laporan yang dapat memenuhi karakteristik berikut:

1. Relevan. Informasi dalam laporan keuangan dapat disebut relevan jika didalamnya mengandung unsur manfaat umpan balik, manfaat prediktif, tepat waktu dan lengkap. 
2. Andal. Informasi yang andal yaitu informasi yang disajikan dengan jujur, dapat diverifikasi, dan netral.

3. Dapat dibandingkan. Informasi yang termuat dalam laporan keuangan akan lebih berguna jika dapat dibandingkan dengan laporan keuangan periode sebelumnya atau laporan keuangan entitas pelaporan lain pada umumnya.

4. Dapat dipahami. Informasi yang disajikan dalam laporan keuangan dapat dipahami oleh pengguna dan dinyatakan dalam bentuk serta istilah yang disesuaikan dengan batas pemahaman para pengguna.

Pemerintah daerah dalam melaksanakan kegiatan operasional dan penyusunan laporan keuangannya dituntut untuk mematuhi peraturan perundang-undangan yang berlaku terkait aktivitas dan penyusunan laporan keuangan. Peraturan Pemerintah Nomor 71 Tahun 2010 tentang Standar Akuntansi Pemerintahan yang merupakan prinsip-prinsip akuntansi yang diterapkan dalam penyusunan dan penyajian laporan keuangan pemerintah agar menjadi berkualitas. Pengendalian Internal dalam sebuah instansi pemerintah merupakan salah satu faktor yang mendukung kualitas laporan keuangan yang dihasilkan instansi pemerintah tersebut (Lumintang et al, 2017). Pengawasan dalam pengelolaan keuangan pemerintah daerah sangat perlu diadakan agar dapat menjamin dan meyakinkan bahwa kegiatan yang dilakukan pemerintah daerah sudah sesuai dengan ketentuan, rencana, kebijakan dan standar yang berlaku (Purboraras, 2019). Pengawasan terhadap aktivitas pemerintahan diatur dalam Peraturan Pemerintah Nomor 60 Tahun 2008 tentang Sistem Pengendalian Internal. Pengawasan internal merupakan keseluruhan dari proses audit, reviu, evaluasi, pemantauan serta pengawasan lain akan penyelenggaraan tugas dan fungsi organisasi untuk memberikan keyakinan yang memadai bahwa kegiatan dilaksanakan sesuai dengan tolok ukur yang telah ditetapkan dengan efektif dan efisien dalam rangka mewujudkan good governance (Peraturan Pemerintah Republik Indonesia tentang SPIP, 2008).

Afiah dan Azwari (2015) menemukan bahwa pengendalian internal berpengaruh signifikan positif terhadap Kualitas Laporan Keuangan Pemerintah Daerah sedangkan Budiawan (2014) menyatakan Sistem Pengendalian Internal sebagai bentuk pengawasan tidak memiliki pengaruh yang positif terhadap Kualitas Laporan Keuangan Pemerintah Daerah. Purboraras (2019) menemukan bahwa kepatuhan akan Standar Akuntansi Pemerintahan mampu mempengaruhi kualitas laporan keuangan sedangkan Setiawan (2017) menyatakan kepatuhan akan peraturan perundang-undangan tidak berpengaruh pada pemberian opini laporan keuangan pemerintah daerah. Pribadi (2015) menunjukkan bahwa baik penerapan Standar Akuntansi Pemerintahan maupun bentuk pengawasan yaitu Sistem Pengendalian Internal memiliki pengaruh yang positif akan kualitas laporan keuangan pemerintah daerah. Lebih lanjut, Pribadi (2015) dan Rahmasari (2017) menyatakan bahwa tingkat kepatuhan suatu entitas akan peraturan perundang-undangan mempengaruhi kualitas laporan keuangan pemerintah.

\section{H1 : Kepatuhan akan peraturan Undang-undang berpengaruh signifikan positif terhadap kualitas laporan keuangan.}

Simangunsong (2014) dan Susilawati dan Riana (2014) menyatakan bahwa pengawasan internal memiliki penguaruh positif terhadap kinerja pemerintah daerah.

H2 : Pengawasan internal berpengaruh signifikan positif terhadap kualitas laporan keuangan.

Berdasarkan hipotesis penelitian, maka Gambar 2 menggambarkan konsep pemikiran dari penelitian ini. 


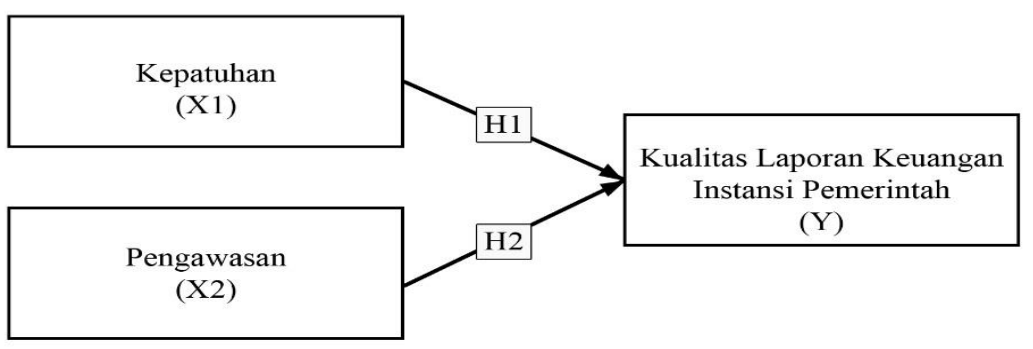

Gambar 2 Kerangka Konseptual Pemikiran

\section{METODE PENELITIAN}

Jenis penelitian ini yaitu kuantitatif dengan metode eksperimen. Populasi dalam penelitian ini adalah pimpinan Organisasi Pemerintah Daerah (OPD) termasuk didalamnya yaitu Aparatur Sipil Negara (ASN) pada Bagian Keuangan yang berada di Kabupaten Minahasa Utara dengan jumlah 87 ASN. Penelitian ini menggunakan purposive sampling dengan kriteria yaitu ASN di suatu OPD yang berhubungan langsung dengan penyusunan dan pelaporan keuangan yaitu Kepala Sub-bagian Keuangan dan seorang anggota serta Pejabat Pengelola Keuangan (PPK-SKPD). Sampel penelitian ini adalah sebanyak 72 sampel.

Terdapat dua variabel independen dalam penelitian ini yaitu kepatuhan (akan peraturan Undang-Undang) dan pengawasan (internal) serta satu variabel dependen yaitu kualitas Laporan Keuangan Pemerintah Daerah. Variabel kepatuhan akan peraturan UndangUndang diukur melalui kesesuaian antara penyusunan dan penyajian laporan keuangan objek yang diteliti dengan Peraturan Pemerintah Nomor 71 Tahun 2010 tentang Standar Akuntansi Pemerintahan dan variabel pengawasan internal didasarkan pada unsur-unsur dalam Peraturan Pemerintah Nomor 60 Tahun 2008 tentang Sistem Pengendalian Internal Pemerintah sedangkan variabel kualitas laporan keuangan pemerintah daerah didasarkan pada karakteristik kualitatif laporan keuangan yaitu relevan, andal, dapat dibandingkan dan dapat dipahami. Variabel independen dan variabel dependen dalam penelitian ini diukur dengan menggunakan skala Likert dengan nilai 1 sampai dengan 5.

Data dalam penelitian ini merupakan jenis data kuantitatif yang bersumber dari data primer. Pengumpulan data dilakukan menggunakan kuesioner yang diadaptasi kuesioner milik Kusumo (2018) dan Nugroho (2018). Alat analisis yang digunakan yaitu analisis statistik parametrik dengan metode analisis data yaitu regresi linear berganda yang dilakukan dengan bantuan aplikasi SPSS versi 23. Dalam proses analisis terdapat uji kualitas data: uji validitas dan uji reliabilitas serta uji asumsi klasik: uji normalitas, multikolinearitas dan heteroskedastisitas. Pengujian hipotesis menggunakan uji statistik $\mathrm{t}$ dan uji koefisien determinasi $\left(\mathrm{R}^{2}\right)$.

\section{HASIL PENELITIAN DAN PEMBAHASAN}

\subsection{Hasil penelitian}

Kuesioner yang disebarkan ada sebanyak 72 eksemplar ke 24 Organisasi Pemerintah Daerah (OPD) dengan masing-masing OPD menerima 3 eksemplar, dan kuesioner yang kembali hanyalah sebesar $83 \%$ atau sebanyak 60 eksemplar. Pengujian pertama yang dilakukan yaitu uji Kualitas Data terdiri dari uji validitas dan uji reliabilitas. Tabel 1 menunjukkan bahwa setiap angka r-hitung dari masing-masing pernyataan dalam kuesioner lebih besar dari r-tabel $(0,2108$ untuk $\mathrm{N}=60$ dan $\alpha=0,05)$ sehingga kesimpulannya setiap penyataan dalam kuesioner yang digunakan adalah valid atau mampu mengungkapkan hal yang ingin diukur oleh variabel. Tabel 1 juga menunjukkan bahwa nilai Cronbach Alpha dari masing-masing variabel lebih besar dari 0,60 sehingga kesimpulannya kuesioner yang digunakan adalah reliabel. 
Tabel 1. Hasil uji validitas dan reliabilitas

\begin{tabular}{|c|c|c|c|}
\hline Pernyataan & $\begin{array}{c}\text { Kepatuhan akan } \\
\text { peraturan Undang-Undang }\end{array}$ & $\begin{array}{c}\text { Pengawasan } \\
\text { Internal }\end{array}$ & $\begin{array}{c}\text { Kualitas } \\
\text { LKPD }\end{array}$ \\
\hline 1 & $0.551^{* * *}$ & $0.808^{* *}$ & $0.758^{* *}$ \\
\hline 2 & $0.655^{* *}$ & $0.826^{* *}$ & $0.720^{* *}$ \\
\hline 3 & $0.696^{* *}$ & $0.706^{* *}$ & $0.738^{* *}$ \\
\hline 4 & $0.720^{* *}$ & $0.787^{* *}$ & $0.762^{* *}$ \\
\hline 5 & $0.573^{* *}$ & $0.771^{* *}$ & $0.679^{* *}$ \\
\hline 6 & $0.761^{* *}$ & $0.699^{* *}$ & $0.802^{* *}$ \\
\hline 7 & $0.721^{* *}$ & $0.677^{* *}$ & $0.827^{* *}$ \\
\hline 8 & $0.578^{* *}$ & $0.736^{* *}$ & $0.664^{* *}$ \\
\hline 9 & $0.581^{* *}$ & $0.726^{* *}$ & \\
\hline 10 & $0.820^{* *}$ & $0.760^{* *}$ & \\
\hline 11 & $0.698^{* *}$ & & \\
\hline 12 & $0.750^{* *}$ & & \\
\hline 13 & $0.722^{* *}$ & & \\
\hline 14 & $0.745^{* *}$ & & \\
\hline 15 & $0.672^{* *}$ & & \\
\hline 16 & $0.673^{* *}$ & & \\
\hline 17 & $0.785^{* *}$ & & \\
\hline 18 & $0.552^{* *}$ & & \\
\hline 19 & $0.552^{* *}$ & & \\
\hline 20 & $0.548^{* * *}$ & & \\
\hline 21 & $0.538^{* *}$ & & \\
\hline 22 & $0.470^{* *}$ & & \\
\hline 23 & $0.777^{* *}$ & & \\
\hline 24 & $0.558^{* * *}$ & & \\
\hline 25 & $0.639^{* *}$ & & \\
\hline 26 & $0.648^{* *}$ & & \\
\hline 27 & $0.660^{* *}$ & & \\
\hline 28 & $0.576^{* *}$ & & \\
\hline Cronbach alpha & 0.949 & 0.913 & 0.878 \\
\hline
\end{tabular}

Sumber: Data olah, 2019

Pengujian kedua yaitu uji asumsi klasik yang terdiri dari uji normalitas, multikolinearitas, dan heteroskedastisitas. Tabel 2 menunjukkan angka hasil uji KolmogorovSmirnov yaitu sebesar 0,200 yang mana lebih besar dari 0,05 sehingga disimpulkan bahwa residual error data telah berdistribusi normal.

Tabel 2. Hasil uji normalitas

\begin{tabular}{llr}
\hline & & Unstandardized Residual \\
\hline Normal Parameters & & 60 \\
& Mean & 0.0000000 \\
Most Extreme Differences & Std. Deviation & 3.12704105 \\
& Absolute & 0.085 \\
& Positive & 0.062 \\
Test Statistic & Negative & -0.085 \\
Asymp. Sig. (2-tailed) & & 0.085 \\
\hline Siumber: Datat 2019 & 0.200 \\
\hline
\end{tabular}

Sumber: Data olah, 2019 
Tabel 3 menyajikan hasil pengujian multikolinearitas dimana nilai tolerance oleh masingmasing variabel adalah lebih besar dari 0,1 dan nilai Variance Inflation Factor (VIF) lebih kecil dari 10 sehingga berarti tidak terdapat masalah multikolinearitas.

Tabel 3. Hasil uji multikolinearitas

\begin{tabular}{|c|c|c|c|c|c|c|c|}
\hline \multirow{3}{*}{ Model } & \multicolumn{2}{|c|}{$\begin{array}{c}\text { Unstandardized } \\
\text { Coefficients }\end{array}$} & \multirow[t]{2}{*}{$\begin{array}{l}\text { Standardized } \\
\text { Coefficients }\end{array}$} & \multirow{3}{*}{$\mathbf{t}$} & \multirow{3}{*}{ Sig. } & \multicolumn{2}{|c|}{$\begin{array}{l}\text { Collinearity } \\
\text { Statistics }\end{array}$} \\
\hline & & Std. & & & & & \\
\hline & B & Error & Beta & & & Tolerance & VIF \\
\hline Constant & 15.894 & 4.251 & & 3.739 & 0.000 & & \\
\hline Kepatuhan & & & & & & & \\
\hline $\begin{array}{l}\text { Peraturan Undang- } \\
\text { undang }\end{array}$ & 0.107 & 0.049 & 0.351 & 2.166 & 0.035 & 0.484 & 2.065 \\
\hline Pengawasan Internal & 0.174 & 0.135 & 0.209 & 1.288 & 0.203 & 0.484 & 2.065 \\
\hline
\end{tabular}

Sumber: Data olah, 2019

Tabel 4 menyajikan hasil pengujian heteroskedastisitas dengan menggunakan spearman rank dimana masing-masing variabel memperoleh angka 0,356 dan 0,386 yang mana lebih besar dari 0,05 sehingga kesimpulannya tidak ada masalah heteroskedastisitas.

Tabel 4. Hasil uji heteroskedastisitas

\begin{tabular}{lllrrrr}
\hline & & & $\begin{array}{c}\text { Kepatuhan akan } \\
\text { Peraturan Undang- } \\
\text { undang }\end{array}$ & $\begin{array}{c}\text { Pengawasan } \\
\text { Internal }\end{array}$ & RES_3 \\
\hline $\begin{array}{l}\text { Spearman's } \\
\text { rho }\end{array}$ & $\begin{array}{l}\text { Kepatuhan akan } \\
\text { Peraturan }\end{array}$ & $\begin{array}{c}\text { Correlation } \\
\text { Undang- }\end{array}$ & $\begin{array}{l}\text { Coefficient } \\
\text { Sig. (1-tailed) }\end{array}$ & 1.000 & $0.757^{*}$ & 0.049 \\
& Undang & N & & 0.000 & 0.356 \\
& Pengawasan & Correlation & 60 & 60 & 60 \\
& Internal & Coefficient & $0.757^{*}$ & 1.000 & 0.038 \\
& Sig. (1-tailed) & 0.000 & & 0.386 \\
& $\mathrm{~N}$ & 60 & 60 & 60 \\
\hline
\end{tabular}

Sumber: Data olah, 2019

Tabel 5 menunjukkan bahwa analisis regresi linear berganda menghasilkan persamaan sebagai berikut:

$\mathrm{Y}=15,894+0,107+0,174$. Persamaan tersebut dapat diinterpretasikan sebagai berikut:

1. Nilai 15,894 merupakan nilai konstanta variabel dependen yaitu kualitas laporan keuangan pemerintah daerah tanpa adanya pengaruh dari variabel independen dan faktor diluar model.

2. Nilai koefisien sebesar 0,107 menunjukkan bahwa variabel X1, Kepatuhan akan Peraturan Undang-undang memiliki hubungan yang positif dengan variabel $\mathrm{Y}$ dimana setiap terjadi kenaikan pada variabel X1 maka akan meningkatkan pula kualitas laporan keuangan pemerintah daerah, dengan asumsi variabel yang lain tetap.

3. Nilai koefisien sebesar 0,174 menunjukkan bahwa variabel X2, Pengawasan Internal memiliki hubungan yang positif dengan variabel Y dimana setiap terjadi kenaikan pada variabel X2 maka akan meningkatkan pula kualitas laporan keuangan pemerintah daerah, dengan asumsi variabel yang lain tetap.

Tabel 5 juga menunjukkan bahwa $\mathrm{H} 1$ yang berbunyi Kepatuhan akan peraturan Undang-undang berpengaruh signifikan positif terhadap kualitas laporan keuangan dapat diterima karena memiliki nilai signifikansi lebih kecil dari 0,05 sedangkan $\mathrm{H} 2$ yang berbunyi 
Pengawasan internal berpengaruh signifikan positif terhadap kualitas laporan keuangan ditolak karena memiliki nilai signifikansi lebih besar dari 0,05 . Pengujian yang terakhir yaitu pengujian koefisien determinasi dimana dari Tabel 5 dapat dilihat bahwa adjusted $R$ square menampilkan angka sebesar 0,247 yang artinya variasi variabel independen dapat memengaruhi variabel dependen sebesar $24,7 \%$ dan sisanya dipengaruhi oleh faktor lain diluar model.

Tabel 5. Hasil analisis regresi linear berganda

\begin{tabular}{lrrrrrr}
\hline \multirow{2}{*}{ Model } & \multicolumn{2}{c}{$\begin{array}{c}\text { Unstandardized } \\
\text { Coefficients }\end{array}$} & $\begin{array}{c}\text { Unstandardized } \\
\text { Coefficients }\end{array}$ & \multirow{2}{*}{ Sig. } \\
\cline { 2 - 4 } & \multicolumn{2}{c}{ B } & Std. Error & B & & \\
\hline Constant & 15.894 & 4.251 & & 3.739 & 0.000 \\
Kepatuhan akan Peraturan Undang-Undang & 0.107 & 0.049 & 0.351 & 2.166 & 0.035 \\
Pengawasan Internal & 0.174 & 0.135 & 0.209 & 1.288 & 0.203 \\
R & 0.522 & & & & & \\
R Square & 0.273 & & & & \\
Adjusted R Square & 0.247 & & & & & \\
Std. Error of the Estimate & 3.181 & & & & & \\
\hline
\end{tabular}

Sumber: Data olah, 2019

\subsection{Pembahasan}

Pengaruh kepatuhan akan peraturan undang-undang terhadap kualitas laporan keuangan pemerintah daerah. Hasil pengujian analisis regresi linear berganda menemukan bahwa kepatuhan akan peraturan Undang-Undang memiliki pengaruh yang signifikan dan positif terhadap kualitas laporan keuangan pemerintah daerah khususnya di Kabupaten Minahasa Utara. Hal ini berarti semakin patuh pemerintah daerah Kabupaten Minahasa Utara pada peraturan Undang-undang maka semakin berkualitas laporan keuangan yang dihasilkan. Ini menunjukkan ada respon yang baik dari Pemerintah Kabupaten Minahasa Utara akan peraturan yang berlaku khususnya SAP. Hasil ini selaras dengan penelitian yang dilakukan oleh Pribadi (2015) dan Purboraras (2019) yang juga menyatakan bahwa kepatuhan akan peraturan Undang-Undang berpengaruh terhadap kualitas laporan keuangan pemerintah daerah.

Pengaruh pengawasan internal terhadap kualitas laporan keuangan pemerintah daerah. Hasil pengujian analisis regresi linear berganda pada Tabel 5 menunjukkan bahwa Pengawasan Internal tidak memiliki pengaruh yang signifikan positif terhadap kualitas laporan keuangan pemerintah daerah sehingga kegiatan pengawasan yang dilakukan tidak akan mempengaruhi kualitas laporan keuangan meski telah diterapkan dengan baik. Hal ini diduga diakibatkan karena kurangnya ASN yang memangku jabatan sebagai penyusun dan penyaji laporan keuangan yang berlatar belakang akuntansi serta pengawasan yang dilakukan oleh auditor eksternal belum begitu efektif atau rutin. Hal ini sejalan dengan hasil penelitian yang dikemukakan oleh Nugroho (2018) dan Rachman (2017) yang mengemukakan bahwa pengawasan internal tidak berpengaruh terhadap kualitas laporan keuangan pemerintah daerah.

\section{KESIMPULAN DAN SARAN}

\subsection{Kesimpulan}

Kesimpulan dari penelitian ini yaitu sebagai berikut:

1. Kepatuhan akan peraturan Undang-Undang berpengaruh signifikan positif terhadap kualitas laporan keuangan pemerintah daerah Kabupaten Minahasa Utara. Artinya semakin patuh pemerintah dalam melaksanakan aktivitasnya sesuai dengan peraturan perundang-undangan maka laporan keuangan pemerintah juga akan semakin berkualitas. 
2. Pengawasan Internal tidak berpengaruh signifikan positif terhadap kualitas laporan keuangan pemerintah daerah Kabupaten Minahasa Utara. Artinya meskipun Pengawasan Internal telah dilaksanakan dengan baik namun tidak akan begitu berpengaruh pada kualitas laporan keuangan pemerintah daerah Kabupeten Minahasa Utara.

\subsection{Saran}

Berikut saran yang dapat diberikan terkait hasil penelitian ini:

1. Bagi pemerintah daerah agar kiranya meningkatkan atau mempertahankan etos kerja terutama dalam pelayanan kepada masyarakat dan tetap melaksanakan serta mengontrol pengawasan internal dengan baik.

2. Bagi penelitian selanjutnya untuk dapat meningkatkan jumlah data/responden pada penelitian yang akan dilakukan agar hasil yang diperoleh semakin akurat dan faktual serta juga meneliti variabel lain yang tidak diteliti dalam penelitian ini agar dapat memperluas referensi pemerintah daerah khususnya Kabupaten Minahasa Utara dalam meingkatkan kualitas laporan keuangannya.

\section{DAFTAR PUSTAKA}

Afiah, N. N., \& Azwari, P. C. (2015). The effect of the implementation of government internal control system (GICS) on the quality of financial reporting of the local government and its impact on the principles of good governance: A research on district, City and Provincial Government in South Sumatera. Procedia - Social and Behavioral Sciences, 211, 811 - 818. https://doi.org/10.1016/j.sbspro.2015.11.172

Budiawan, D. A., \& Purnomo, B. S. (2014). Pengaruh sistem pengendalian internal dan kekuatan koersif terhadap kualitas laporan keuangan pemerintah daerah (Studi pada pemerintah daerah kabupaten/kota di wilayah I Bogor Provinsi Jawa Barat). Jurnal Riset Akuntansi dan Keuangan, 2(1), 276-288. https://doi.org/10.17509/jrak.v2i1.6581

Kusumo, G. R. (2018). Analisis faktor-faktor yang mempengaruhi kualitas laporan keuangan pemeritah daerah (Studi empiris pada Satuan Kerja Perangkat Daerah Pemerintah Kabupaten Bantul). Skripsi. https://dspace.uii.ac.id/handle/123456789/8421.

Nugroho, B. S. (2018). Pengaruh penerapan standar akuntansi pemerintah, kompetensi sumber daya manusia, penerapan sistem pengendalian intern, pemanfaatan teknologi informasi dan komitmen organisasi terhadap kualitas laporan keuangan pemerintah daerah (Studi empiris pada Badan Keuangan Daerah (BKD) Kabupaten Boyolali). Skripsi. http://eprints.ums.ac.id/id/eprint/66006

Lumintang, G. S., Lambey, L., \& Tangkuman, S. (2017). Analisis pengaruh sistem pengendalian intern dan implementasi sistem akuntansi keuangan daerah (SAKD) terhadap kualitas laporan keuangan pemerintah daerah. Jurnal Riset Akuntansi Going Concern, 12(2), 950-962. https://doi.org/10.32400/gc.12.2.18372.2017

Peraturan Pemerintah Republik Indonesia Nomor 60 Tahun 2008 tentang Sistem Pengendalian Intern Pemerintah.

Peraturan Pemerintah Republik Indonesia Nomor 71 Tahun 2010 tentang Standar Akuntansi Pemerintahan.

Pontoh, W. (2013). Akuntansi konsep dan aplikasi, Edisi Pertama, Cetakan Pertama. Jakarta: Halaman Moeka.

Pribadi, A. (2015). Pengaruh penerapan standar akuntansi pemerintahan dan sistem pengendalian internal pemerintah terhadap kualitas laporan keuangan pemerintah daerah (Studi kasus pada dinas pengelolaan keuangan dan aset daerah Kota Bandung). Skripsi. http://repository.widyatama.ac.id/xmlui/handle/123456789/6485. 
Purboraras, S. A. (2019). Pengaruh kepatuhan standar akuntansi pemerintah, pemanfaatan sia keuangan daerah, pelatihan dan pengawasan terhadap kualitas laporan keuangan (studi pada organisasi pemerintah daerah di Kabupaten Blitar). Jurnal Ilmiah Mahasiswa Fakultas Ekonomi dan Bisnis, 7(2), 1-11. https://jimfeb.ub.ac.id/index.php/jimfeb/article/view/5522

Rachman, A. A. (2017). Internal control, good cooperative governance and performance. International Journal and Scientific and Technology Research (IJSTR), Vol.6 Issue 11 November 2017, 245-252. https://www.ijstr.org/paper-references.php?ref=IJSTR$1217-18281$

Rahmasari, D. (2017). Pengaruh sistem pengendalian internal, kepatuhan terhadap perundang-undangan, tindak lanjut rekomendasi hasil pemeriksaan dan total aset terhadap opini audit dengan tingkat pengungkapan pada catatan atas laporan keuangan kementerian/lembaga sebagai variabel intervening. Skripsi. http://digilib.unila.ac.id/id/eprint/29421

Setiawan, R. A. (2017). Pengaruh sistem pengendalian intern dan kepatuhan pada peraturan perundang-undangan terhadap opini laporan keuangan pemerintah daerah. Skripsi. http://repository.unhas.ac.id/handle/123456789/23251

Sholohah, S. A., Sulistyawati, A. I., \& Santoso, Aprih. (2019). Kualitas laporan keuangan dan faktor-faktor yang mempengaruhinya. Indonesia Accounting Journal, 1(2), 45-56. https://doi.org/10.32400/iaj.26622

Simangunsong, R. (2014). The impact of internal control effectiveness and internal audit role toward the performance of local government. Research Journal of Finance and Accounting $5(7)$

$50-58$. https://www.iiste.org/Journals/index.php/RJFA/article/view/12308

Susilawati, \& Riana, D. S. (2014). Standar akuntansi pemerintahan dan sistem pengendalian intern sebagai anteseden kualitas laporan keuangan pemerintah daerah. STAR - Study and Accounting Research, 11(1), 15-32. http://stembi.ac.id/file/2.\%20Susilawati,\%20Dwi\%20Seftihani\%20Riana\%20(STAR $\left.\% 20 \mathrm{Vol} \% 20 \mathrm{XI}, \% 20 \mathrm{No}_{2} 201 \% 20-\% 202014\right)$.pdf 